\title{
Harmonization of Green Motives and Green Business Strategies towards Sustainable Development of Hospitality and Tourism Industry: Green Environmental Policies
}

\author{
Zahid Yousaf ${ }^{1, *}\left(\mathbb{D}\right.$, Magdalena Radulescu ${ }^{2,3}, *$, Crenguta Ileana Sinisi ${ }^{4} \oplus$, Luminita Serbanescu ${ }^{2}$ \\ and Loredana Maria Paunescu 5
}

check for updates

Citation: Yousaf, Z.; Radulescu, M.; Sinisi, C.I.; Serbanescu, L.; Paunescu, L.M. Harmonization of Green Motives and Green Business Strategies towards Sustainable Development of Hospitality and Tourism Industry: Green Environmental Policies. Sustainability 2021, 13, 6592. https://doi.org/ $10.3390 /$ su13126592

Academic Editors: Pantea Foroudi,

Maria Palazzo and

Dan-Cristian Dabija

Received: 26 April 2021

Accepted: 2 June 2021

Published: 9 June 2021

Publisher's Note: MDPI stays neutral with regard to jurisdictional claims in published maps and institutional affiliations.

Copyright: (c) 2021 by the authors. Licensee MDPI, Basel, Switzerland. This article is an open access article distributed under the terms and conditions of the Creative Commons Attribution (CC BY) license (https:// creativecommons.org/licenses/by/ $4.0 /)$.
1 Higher Education Department, Government College of Management Sciences, Mansehra 21300, Pakistan

2 Department of Finance, Accounting and Economics, University of Pitesti, 110040 Pitesti, Romania; luminitaserb@yahoo.com

3 Doctoral School University "Lucian Blaga" Sibiu, 550024 Sibiu, Romania

4 Department of Management and Business Administration, University of Pitesti, 110040 Pitesti, Romania; crengutaileana77@gmail.com

5 Department of Cybernetics, Economic Informatics, Finance and Accounting, University Petroleum-Gas of Ploiesti, 100680 Ploiesti, Romania; loredana.paunescu@yahoo.com

* Correspondence: muhammadzahid.yusuf@gmail.com (Z.Y.); magdalena.radulescu@upit.ro (M.R.); Tel.: +92-321-980-4474 (Z.Y.)

Abstract: This study aims to investigate the direct impact of green motives (GM) and green business strategies (GBS) on sustainable development (SD) in the hospitality sector. It explores the direct links between GM and SD. Moreover, the mediating role of GBS between GM and SD was tested. The research relies on the stakeholders' theory, which states that the organization's success and future development depends on the satisfaction of stakeholders. Data were collected from 451 top managers and owners from 54 hotels (5, 4 and 3-star hotels) operating in Pakistan. Quantitative analysis including correlation, regression, confirmatory factor analysis and structural equation model techniques were used. The mediating role of GBS was assessed using the bootstrapping method. Results proved that GM and GBS enable hotel industry to achieve the targets of SD. Finding also proved that GBS act as a mediator between the GM and SD link. The hotel industry needs attention to achieve the targets of SD and customers' inclination towards more hygienic and environmental issues after the worldwide COVID-19 pandemic situation has forced the hotel industry to adapt GBS initiated through GM. The current research articulated this upcoming issue and offered a SD model for the hotel industry.

Keywords: sustainable development; hotel industry; green motives; green business strategies

\section{Introduction}

The notion of sustainable development (SD) remained the topic of interest for all kind of organizations in developing economy. SD is a more challenging task for the developing countries that lack large financial resources to cope with the environmental-related problems. Sustainable development requests new business models implemented in all the economic sectors for achieving sustainability [1]. Business organization should share their experiences, good practices, create awareness of the economic benefits of sustainability and measure impacts [2]. The tourism's potential to drive sustainable development is growing. Tourism has the potential to contribute to all the 2030 Sustainable Development Goals [3].

The current business world is facing health-safety threats to its sustainable development [4]. The ecological issues and more suitable utilization of resources have been gaining the interest and attention among different businesses and academic disciplines [5]. The prime reason for this concern is threats to the health and safety of global health from the business production activities [6]. The green motives and green strategies were not fully 
considered until recently in the research area. Research recognized the importance of the "green" concept in the business sector [7]. Most of the businesses are now compelled to follow the models of green motives and green business strategies due to the pressure of stakeholders [8]. The results of implementing green strategies were both in the achieved profit area, but also in the relations area of the corporations with their stakeholders. Implementing such green strategies can help companies to capitalize benefits in a more restrictive environmental frame. However, there is hardly any study about the achievement of SD through green motives and green business strategies. Hence, an explicit research study is required to investigate the impact of green motives and green business strategies on SD. Green strategies majorly depend upon multiple green motives. Green motives include cost reduction by energy conservation, removal of waste production and stake holder's affinity towards environmental protection [9].

The "green" concept is now widely used in industrial sectors and other areas like the green product [10], green marketing [11] and green management [12]. The remarkable deliberations on the nexus between the green motives and green business strategies demonstrated that those can be used to easily attain the sustainable development goals [13]. There are some studies $[14,15]$ aiming to analyze the green motives in the hospitality area, which concluded that these are represented by the cost cut or reducing the waste for improving its efficiency and improving the image for their customers or responding the suppliers 'pressures regarding the environment protection, but they failed to measure exactly the result of implementing the green practices or their outcomes was not validated for all the organizations involved in the studies. However, given the lack of research on this specific topic, there is hardly any evidence about green motives and their influential role together with the green business strategies for achieving the sustainable development. Moreover, the strong relationship between GBS and sustainable development shows that this variable ca not be the only one impacting on the SD. This is why we have aimed to analyze the GM as a predictor for GBS and the mediating role of GBS between the GM-SD link, because the GBS mediating role was not analyzed so far. No previous research has tried to build a comprehensive model to evaluate the SD goals through multiple dimensions of GBS in the organizations.

The aim of this research is to study the relation between green motives, green business strategies and the sustainable development goals in the tourism and hospitality sectors, given the major role of this sector for all the economies and especially for the developing countries. Thus, the focus of this study is on the sustainable development of the hotel and tourism industry in relation with the environment and long term goals of business growth, because of the tight relation between the tourism activities and natural environment and a tight relation between the tourism sector and increasing the efficiency of the entire economy, its significant role in achieving the sustainable economic growth, by implementing sustainable technological changes, reducing the resources waste and improving the overall business performance. For expanding and enhancing the existing research, we also added a mediator into this business model and investigated the mediating role of the green business strategies for the green motives-sustainable development link.

The SD concept focuses on the development of a business, which is beneficial for both the business and the environment [16]. Green strategies mainly focus on environmental protection, which is concerned about the removal of resources waste and improving the quality of consumer product [17]. Thus, it is beneficial to research the green strategies considering the sustainable development for designing and implementing sustainable business models for the companies.

Tourism is the second sector contributing to the GDP growth at the world level with a share of $9.8 \%$, after the financial and banking sector [18]. Especially for the developing countries (such as Pakistan), tourism represents a major source of income. Ashley et al. [19] have demonstrated that tourism can support almost $40 \%$ of GDP in developing countries. Fuel energy consumption to travel to destinations represents almost $30 \%$ of the total energy consumption worldwide and generates $75 \%$ of the total greenhouse emissions generated 
by tourism-related activities [20]. This causes a rise of the greenhouse emissions and climate change [21]. The tourism sector contributes up to around $8 \%$ to total greenhouse emissions at the international level [22,23]. Previous studies have emphasized that mass tourism is causing many problems despite the economic gains such as consuming rare resources and polluting the environment [24-26]. Due to all those reasons and due to the importance attached to the fulfilment of the 2030 SDGs, there have been growing calls from researchers for the tourism sector to take urgent steps to manage and target the sustainable development issues $[27,28]$.

The managers in the tourism industry can increase the general importance of the environment protection by continuously promoting the sustainable consumption of the tourists as part of the green strategies they have applied [29]. The tourists and other stakeholders became more and more aware of the environmental impact of the tourism-related activities; tourists are willing to pay more on environmental-friendly products and services, seek for green certificates and ecolabels [30,31] and all the stakeholders have started to appreciate much more the ecofriendly environment behavior of the tourism and hospitality actors [32] This study would be helpful for the managers of businesses to craft valuable green business strategies in order to attain the sustainable development of the tourism industry. Hotel industry is a key element for the tourism sector and it has a major role in protecting and preserving the environment as hotels use large amounts of natural resources [33]. Sustainable practices in tourism and hotels support the environment protection, but they also reduce costs and waste; the environmental sustainability is considered a major part of the overall sustainable development [34]. Therefore, our research relies on a survey conducted into the hotel industry in Pakistan.

\section{Literature Review}

\subsection{Green Motives and Sustainable Development}

The concept of "Green" is widely preferred by a broad group of people belonging to diverse societies. The Earth's inhabitants who are especially associated to the global health seem to use the concept of "green" by explaining its benefits, i.e., actions that cause relatively less damage to the environment [6]. The term "green" shows that businesses and humans are friendly to the environment. Therefore, businesses are putting more efforts in greening the business sector for achieving stability under the scope of green motive [35]. Many theories have been provided in this perspective like institutional theory, which deals with the relationship between business and the natural environment. It discusses the global societal pressure regarding environment upon the businesses, that certainly affects the business processes [36]. Institutional theory states that the major reason behind the adoption of environment-friendly policies is represented by the social and legal pressure that businesses must face, for their survival [37]. Achieving stability and maximization of profit by applying the green practices, which are based on the green motives [38] can be further explained under three heads, i.e., moral, instrumental and relational motives.

Moral motives are based on virtue and ethical standards. Businesses must play a positive role in environmental protection to improve future life on Earth [39]. Based on moral motives companies out of their rules and laws adapt green practices in support of sustainable development. Moral motives help the company to compete in the best way by developing new sustainable practices [40]. Instrumental motives are driven by self-interest. To cut the expenses, companies implement green practices by decreasing material and energy consumption. Instrumental motives are based on companies' personal benefits and interest. Under the influence of instrumental motives, companies involve themselves in such green practices that reduce waste material, which leads to cost reduction [41]. Relational motives are linked with the relationship between the company's stakeholders. To create balance among the stakeholders' interests, companies are required to develop social legitimacy [42]. Legitimacy in actual is a relational motive as it explains how the practices of companies are affecting the other actors. To compete effectively it is a dire necessity for companies to cope up with the stakeholders' norms [43,44]. Stakeholder theory is another 
important theory in perspective of green motives that leads towards the sustainability. Green motives such as moral, instrumental or relational are beneficial for sustainability. It is useful for companies to identify such practices and system that leads to excellent sustainable development [45]. The achievement of sustainable development is possible through green motives. Companies are experiencing global pressure to adopt green motives, but those who have green motives are going swiftly on the path of sustainable development [46].

The entire society became more interested in the sustainability goals and thus requests more sustainable models in the development of the business and of entire economy. Consumers request more information about the sustainability of available products or services and its environmental features [47].

Application of green motives supports the company in gaining sustainability by responding to natural environmental protection. Green motives in term of moral motives, instrumental motives and relational motives ensure sustainable development through increasing virtue manner, improving efficiency and saving energy resources. Green motives help to decrease the material waste and minimize the risks, which set the strong foundations for the sustainable development [48]. Green motives are the key elements that lead to satisfying the stakeholders' environmental demands. By enhancing the environment and producing positive effects on environment, the companies can improve their sustainability in a cost-effective way $[48,49]$ proving that the main motive for hotels to adopt ecolabels is represented by the fact that this is good for the environment, but also for the image of the company.

In the current decade, the hospitality and tourism industry companies can successfully integrate environmental practices in their strategies more enthusiastically and proactively [50]. Green motives in terms of instrumental, relational and moral motives [51] can open the new corridors of many favorable outcomes for the hotel industry [52]. Stakeholders are keen to participate in green activities in the hotel industry because of their entrenched motivations [53]. Therefore, the green practices should receive major attention in order to keep the stakeholders motivated for achieving sustainable development. The leading international hotels are strengthening their commitment to sustainability and are integrating it into their strategic plan [54]. Therefore, we hypothesize:

\section{Hypothesis 1 (H1): Green Motives positively influence the Sustainable Development.}

\subsection{Green Motives and Green Business Strategies}

Due to the massive carbon emission, pollution, rapid increase in harmful waste and emergence of serious threats to the environment, the past few decades have changed the priorities of the business and shifted the focus of the business world towards environmental protection and conservation of natural resource [55]. Therefore, the green motives build a very strong foundation for the implementation of the green business strategies. Green business strategies refer to the strategies in which a company shows interest in the safety and protection of the environment. Green business strategies, i.e., derived from green motives, are concerned of adopting manufacturing and service activities that are safe for the environment and that are sustainable over time [56]. More companies are actively adopting the green strategies through green moral motive of business in the perspective of the environmental protection [57].

The environmental concerns are imperative for entrepreneurs as they directly get influenced by the green motives $[58,59]$ and adopt green business strategies for gaining the trust of the customers and other business' stakeholders. Therefore, we argue that the green motives in term of moral motives, instrumental motives and relational motives help to implement the green business strategies for maintaining the ethical standards and for contributing to the safety of the entire world. Green business strategies initiated through the green motives encourage businesses to get the advantage of modern green processes for minimizing wastage [13]. The industrialization has affected the environment drastically in the past few decades. Global warming and carbon footprint are serious challenges and 
lead to the implementation of some necessary actions. Most consumers and stakeholders are concerned about the protection and safety of the environment. Therefore, it is necessary for businesses to focus on the green motives for implementing the green business strategies [60]. In the present competitive era, sustainability and growth of the business depend upon the preferences and interest of customers and stakeholders [45]. These customers and stakeholders are highly motivated towards green business. Thus, businesses focusing on the green strategies created through the green motives can minimize the pressure exerted by the stakeholders and customers. The green business strategies initiated through the green motives fundamentally concentrate on minimizing pollution and avoiding the harmful activities for the environment. Green motives support the design of the environmentally friendly policies for implementing some suitable actions [61]. The green business strategies help managers to get involved in important green activities through green motives: moral, relational and instrumental motives [62]. The increased customers' attention towards environmental sustainability determined the managers of hotels to adapt their business models by implementing green practices, which supports the goal of gaining a competitive advantage and increasing their market share because they attract the customers that are concerned with the green sustainability [63]. Abdou et al. [64] have stated in their study for hotels in Egypt that the main motivation for adopting green star criteria and for implementing green practices was represented by the hotels' commitment to the environmental protection (a moral green motive), which reflects the increased awareness of hotel operators towards protecting the environment and ensuring sustainability.

So, based on all the above discussion, the following hypothesis can be elaborated:

Hypothesis 2 (H2): Green motives positively influence the green business strategies.

\subsection{Green Business Strategies and Sustainable Development}

Sustainable development is an achievement of the economic development stage, which supports the achievement of the current organizational needs while protecting the natural resources for future use [48]. The reason behind application of the green business strategies is to attain sustainability by reaching competitiveness and ecological improvement [65]. By adopting the green strategies, businesses can lower the energy-wastage and minimize its cost. Strategies with the green concept improve the waste management process and remove the adverse effect of the business process on the environment [66]. Green business strategy in term of legitimization also plays a major role to achieve the targets of the long-run sustainability. Green strategies help to remove the chances of penalties or legal charges and shorten the expected risks that are required for the sustainable development. By adopting the green strategies, a business can extend its growth, as the green approach leads to a persistent innovation in products, services and processes [67].

Green business strategies are not concerned of the removal of the resources that cannot be recycled, but rather direct the companies to adopt such activities that minimize negative effects on the environment [68]. Therefore, the first concern of the green business strategies is how to shape the driving forces in a way that is favorable to the business in order to achieve the sustainable development. By adopting the green business strategies, the companies can improve their performance by minimizing their costs along with gaining some modern and effective technological and competitive advancements [69]. It could be argued that going green may decrease the costs by minimizing the waste and using the resources more effectively in the production process. Such efficiency in the use of the resources helps the business to gain a strong position in the market and maintain its sustainability [70]. Furthermore, the green business strategies encourage the mechanism to adopt the latest and modern ideas and improved products, which are ecofriendly for achieving the sustainability goals. The profit-maximizing approach demonstrated that companies can go for green in order to achieve their objectives and strategies, to increase performance and for the business growth, which ultimately leads them towards a sustainable development [71]. Along with all these cost and efficiency motivations, the green 
business strategies also focus on improving the organizational capabilities that are related to ecologically responsible business actions. The businesses that focus on the environmental protection strategies seem to develop unique and competing organizational capabilities that increase business competitiveness and sustainable development [39]. The results of such capabilities represent an innovative product that is best suited to the environment, which ultimately gains the support of the customers and all other stakeholders. The safe products that incorporate a low energy consumption support the businesses for making it a consumers' priority, which finally leads to the sustainability [72]. Sustainability is a major goal in many sectors, including the tourism one, where sustainability is a main issue for tourism further development [73]. Many hotels have started to implement environmental policies to preserve the environment and for the wellbeing of population [74]. Abdou et al. [64] have proved in their study conducted for 4-star and 5-star hotels in Egypt that apply green practices that those green practices support the achievement of some SD goals, especially the SD goals related to the environment. International hotel chains have largely adopted green management practices and proclaimed their commitment to target the SDGs comparing to the independent hotels; this can be explained by high benefits they gain from the economies of scale supported by the uniform business practices they implement [75].

As all the above discussion has provided evidence that the green business strategies can support the businesses to achieve the sustainable development, we settle the following hypothesis:

Hypothesis 3 (H3): Green business strategies positively influence the sustainable development.

\subsection{Mediation Role of the Green Business Strategies between Green Motives-Sustainable Development Link}

The green business strategies should represent a mediator between green motives and sustainable development, as green motives help to improve the green business strategies and the sustainable development is based on the green business strategies [76,77]. Previous researchers have already discussed the influential role of the green motives in the perspective of adopting some green business strategies [67]. As green business strategies lead the businesses to the profit maximization, increase the stakeholders' support and increase business performance due to the innovative ideas, all these ultimately lead to sustainable development [67]. There are always some motives behind designing and adopting various business strategies. The green motives force organizations to adopt green business strategies. These motives could be represented by the sense of social responsibility, the stakeholders' pressure or competitiveness. Green motives push the businesses to adopt green strategies for innovating and for competitiveness to achieve sustainability [78]. Green motives have supported the green business strategies in a more useful way to uplift the business potentials for achieving the sustainable development [79]. In the everchanging business environment, only those businesses that recognize and make strategies according to those changes can resist. Currently, the biggest change in the business trends is to show great care towards the health and safety of the Earth and environment [80]. Only those businesses that recognize the importance of this change have green motives and adopt green strategies can accordingly accomplish the sustainable development. Not going green can damage the image of the organization, decrease stakeholders' support and, eventually, negatively affect the business performance [81]. However, the sustainable development is the main objective for any business; for achieving these objectives, the businesses must adopt green business strategies [82].

Green motives focus on developing the green products that are cost-efficient in the production process and consume fewer energy resources. A green product that is environmentfriendly is now an outcome of this greening strategy that has gained all stakeholders' support and provides a solid basis for its sustainable growth in the safest way [83]. Such green business strategies initiated through green motives can offer a platform to achieve sustainability [84]. Due to the modern business affinity toward the environment protection, 
the businesses are directly influenced by the moral, instrumental and relational motives in elaborating green business strategies to increase their overall sustainability [85]. This has determined the companies to follow the sustainability principles for improving their image. So, based on all these, it can be stated that green business strategies act as a driver of the green motives in order to achieve the sustainable development. Our discussion leads to the following hypothesis:

Hypothesis 4 (H4): Green business strategies act as a mediator which enhances the influence of the green motives on the sustainable development.

Figure 1 shows theoretical framework of this study.

H1

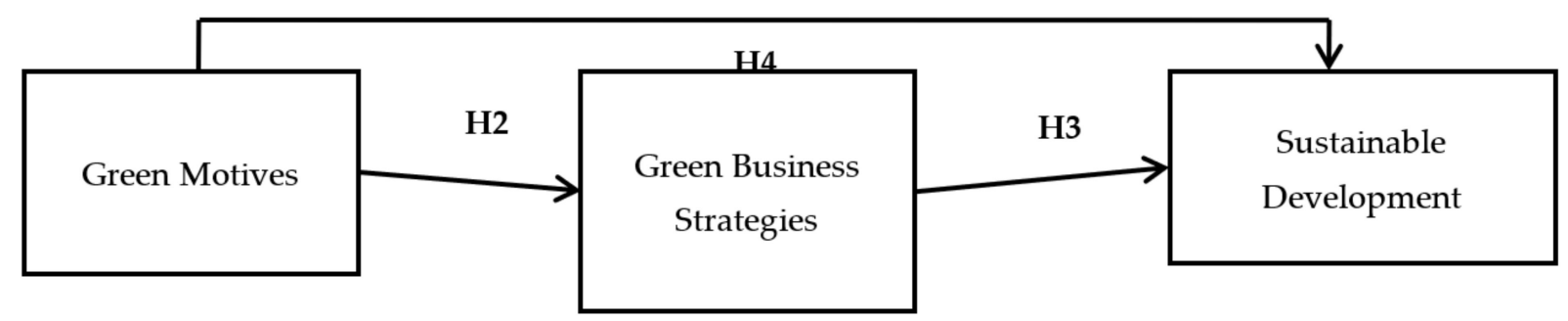

Figure 1. Theoretical framework.

\section{Methodology}

\subsection{Data Collection}

The survey was conducted among 451 top managers and owners in 54 hotels operating in Pakistan in three phases, with a three months distance between them. These 54 hotels include fifteen 5-star hotels, twenty-eight 4-star hotels and eleven 3-star hotels (according to the structure of the hotel industry in Pakistan). The hotels were selected because the results should be generally acceptable, so the 5-star, 4-star and eleven 3-star hotels are more representative and can depict a clear picture of the overall hotel industry around the world.

The purposive sampling scheme was used for this study. The list of 54 hotels $(3,4$ and 5 star hotels) was finalized following the guidelines of [86], which was based on 3 criteria; (1) Hotels should consist of luxurious, high-class buildings and enough space. (2) Hotels provide high-quality services, which met international the requirements of international visitors. (3) National/international visitors, celebrities, international tourists, etc., have stayed there. A total of 54 hotels were Pakistan-based hotels and the data were collected from those management members who were involved in the decision making process and involved in policy making for achieving SDG.

Pakistan is the 5th most populous country of the world and is located at the crossroads of Asia and Arabian sea. Moreover, Pakistan is very attractive for international tourists due to a number of offerings like its beautiful natural locations, cordial attitude of Pakistani people, highest globally reputed rocky mountains (e.g., Nanga Parbut and K2), largest Batura glaciers, etc. Pakistani tourism and hotel industry have gained massive attention at the international level by offering a cordial attitude towards tourists, beautiful and unique landscapes and very good transport infrastructure. The hotel and tourism activities have significantly increased in Pakistan during the last three decades [87]. Tourist receipts increased five times during 1980-2011 in Pakistan [88,89] and slowly decreased after 2011 up to present, but they still remain close to their 2011 level.

These selected hotels present the true picture of the hotel industry in Pakistan because these are internationally rated as foreign delegations and international tourists stay there. The list of 54 hotels was prepared through different sources, which include the Ministry of Tourism-Pakistan, Pakistan Hotel Development Limited (PHDL, Islamabad, Pakistan), Pakistan Hotel Association and Pakistan Services Limited (PSL, Lahore, Pakistan). 
The reason for choosing these international rated hotels is represented by the fact that the international hotel chains have largely adopted green management practices and proclaimed their commitment to target the SDGs comparing to the independent hotels; those GBS support the achievement of the SD goals [64,75].

The data were collected during February 2020 and August 2020. The questionnaire was tested before with 5 university teachers and 15 persons. First, we contacted 600 managers through personal and professional contacts and 522 showed willingness to participate in the survey. The sample size was based on the guidelines presented by other authors [90,91] that showed that a sample size of 500 is very good.

The managers received a covering letter that explained the aim of this research and ensured anonymity. Five Ph.D. students were recruited and trained to collected data. Firstly, the independent variable data were gathered. Data about age, gender, education and work experience were also firstly collected. Secondly, mediator data were gathered and thirdly there were assembled data on the dependent variable. We got 478, 463 and 458 filled questionnaires in those three consecutives phases of the research. Moreover, seven surveys were not fully filled in and were removed from the research. Thus, a total of 451 fully completed questionnaires were analyzed in testing the proposed relationships stated in the hypotheses.

Achieved responses were processed by SPSS 24.0 and AMOS 7.0. The final sample included $52.8 \%$ males and $47.2 \%$ females. In terms of education, $57.6 \%$ respondents had undergraduate studies and $42.4 \%$ respondents had master's studies. The average age and work experience of the respondents were 36.21 years and 7.16 years, respectively. Data were assembled in three different phases to prevent common variance method [92]. In order to check the data for common method variance, Herman's single factor was estimated [92]. All the items were merged into a single factor, which can explain $21.17 \%$ of the total variance, and it was well below the maximum admitted level—50\% [93], so the common method bias was not a problem for our dataset.

\subsection{Variables and Measures}

The estimated factors were measured on Likert scales from 1 (strongly disagree) to 5 (strongly agree). The questionnaire was developed by adapting items from the existing literature for multiple dimensions of green motives, green business practices and sustainable development (all the items are presented in detail in Appendix A-Table A1).

This study focused on investigating the development of SD through GM and GBS in hospitality sector, which is highly related with the experimental analysis. Hence, the subjective measures are most suitable for this context, as the subjective measures deals with what the respondents have actually experienced about specific phenomena [93,94]. Therefore, in this study we used subjective measures for the data collection.

\subsubsection{Green Motives}

Green motives were estimated with its three-dimensions: moral motives (4-items), instrumental motives (3-items) and relational motives (3-items). This scale was adapted from the work of Chang [50].

\subsubsection{Green Business Strategies}

Designing the GBS scale was based on the work of Bıçakcıŏlu [95] and Yasir et al. [96]. This scale was operationalized with six subdimensions. The GBS scale was measured by its six extents: green marketing (6-item scale), green production (3-item scale), green $\mathrm{R}$ and $\mathrm{D}$ (3-item scale), green purchasing (4-item scale), green HRM (2-item scale) and green finance (3-item scale) $[95,96]$.

\subsubsection{Sustainable Development}

This study followed the definition of SD according to "The World Commission on Environment and Development". SD refers to advanced methods used for optimal utiliza- 
tion of assets, making reasonable investments, enhancing technological development and corporate-revolution according to the existing demands. SD is pertinent to establish some different national developmental levels, from economic growth to economic development. SD is an upcoming issue and even UN SDGs recognize the need to accommodate these socioeconomical, environmental and technological challenges [97].

The SD defined in this study covers environmental issues by implementing new innovative technologies, but also the long term goals of business growth, i.e., the first two dimensions of our SD are (1) competitiveness and (2) business performance enhancement. These dimensions of SD are the major basis for measuring long-term business growth, which ensures the sustainable economic growth of the entire economy. Thus, in this study we refer to $\mathrm{SD}$ in terms of ensuring environment protection, business competitiveness and performance for achieving the sustainable economic growth.

The requirement of our study therefore followed already tested scale and the construct of the sustainable development scale was adapted from the work of Singla et al. [98]. This scale was measured with its four major dimensions: competitiveness (8-item scale), business performance enhancement (9-item scale), technological development (8-item scale) and customer satisfaction (9-item scale) [98].

\section{Analysis}

\subsection{Means and Correlations}

Firstly, our research has investigated the correlation matrix, because we targeted to study the association among variables whether the correlation is positive or negative. Mean and correlation values of the analyzed variables are displayed in Table 1. The analyzed variables are positively correlated at the $1 \%$ significance level.

Table 1. Means and correlations.

\begin{tabular}{ccccccccc}
\hline Construct & Mean & SD & $\mathbf{1}$ & $\mathbf{2}$ & $\mathbf{3}$ & $\mathbf{4}$ & $\mathbf{5}$ & $\mathbf{6}$ \\
\hline 1. Age & 2.94 & 0.8 & 1 & & & & & \\
2. Education & 3.28 & 0.7 & 0.07 & 1.00 & & & \\
3. Experience & 3.11 & 0.8 & 0.09 & 0.08 & 1.00 & & \\
4. Green motives & 3.43 & 0.9 & 0.06 & 0.10 & 0.11 & 1 & $31^{* *}$ & 1 \\
5. Green business strategies & 3.22 & 0.13 & 0.11 & 0.14 & 0.10 & $16^{* *}$ & $0.38^{* *}$ & 1 \\
6. Sustainable development & 3.01 & 0.11 & 0.12 & 0.13 & 0.09 & 13 \\
\hline
\end{tabular}

Note: $n=451 .{ }^{* *} p<0.01$ level (2-tailed). SD = Standard deviation.

The value of the significant correlations shows the relationship between two of more variables $[94,99]$. The value of the correlation shows that GM were positively and significantly related to GBS $(b=0.31, p$ value $=0.000)$ and sustainable development $(b=0.16$, $p$ value $=0.000$ ). Results of the correlation shows that GM and SD were also positively and significantly related $(b=0.38, p$ value $=0.000)$.

\subsection{Estimation Model}

Our estimation model consisted of green motives (GMs), green business strategies (GBSs) and sustainable development (SD). The measurement model was assessed using CFA. All the items loaded significantly on their respective constructs. The adequate values of the ratios- $\chi 2(1999)=3499, \chi 2 / \mathrm{df}=1.75, \mathrm{RMSEA}=0.04, \mathrm{CFI}=0.91, \mathrm{IFI}=0.91$ and TLI $=0.91$-indicate that the measurement model is well-fitted for the data.

Table 2 shows that average variance extracted $>0.50$, average shared variance $<$ maximum shared variance and both maximum shared variance and average shared variance $<$ average variance extracted for all the variables. AVE results show that all values are not less than 0.5 thus, our results fulfill the criteria of Fornell and Larcker [100]. So, we proved the convergent validity of our model. Moreover, the square root values of average variance extracted (bolded values on the diagonal of Table 2) of all the variables were greater than their interconstruct correlations. The results stress that all the values of Cronbach's alpha and composite reliability 
are greater than 0.7 , being adequate [94]. Thus, the scales demonstrated adequate levels of discriminant validity and convergent steadiness. Cronbach alpha $(\alpha)>0.70$ (Table 2) show that the internal steadiness of the scales was also adequate. After confirming the convergent and discriminant validity, we proceeded with the structural model.

Table 2. Reliability and convergent validity and discriminant validities (model 1).

\begin{tabular}{lccccccc}
\hline \multicolumn{1}{c}{ Construct } & $\mathbf{1}$ & $\mathbf{2}$ & $\mathbf{3}$ & $\mathbf{A}$ & AVE & MSV & ASV \\
\hline $\begin{array}{l}\text { 1. Green motives } \\
\begin{array}{l}\text { 2. Green business } \\
\text { strategies }\end{array}\end{array}$ & 0.8 & & & 0.79 & 0.59 & 0.10 & 0.08 \\
$\begin{array}{l}\text { 3. Sustainable } \\
\text { development }\end{array}$ & 0.3 & 0.8 & & 0.83 & 0.61 & 0.26 & 0.18 \\
\hline
\end{tabular}

Notes: $n=451$ MSV $=$ Maximum shared variance. ASV $=$ Average shared variance. AVE $=$ Average variance extracted. Bolded values on the diagonals of columns $2-5$ are the square root values of AVE.

\subsection{Structural Model—Direct and Mediation Results}

The validity of our model can be checked using the technique of structural equation modeling [101]. Previous studies [102] considered partial least squares SEM appropriate for many research models, due to their less restrictions for the sample size and residual distributions. The structural model refers to testing of the elaborated hypotheses for investigating the association between the variables included into the model. Therefore, based on the regression analysis, we investigated the structural model we built.

The direct association of the GM with the sustainable development was examined in structural model 1. The findings display a significant positive relationship between the GM and the sustainable development $(\beta=0.23, p<0.001)$. The adequate values of the ratios- $\chi 2(894)=1878.25, \chi 2 / \mathrm{df}=2.01, \mathrm{RMSEA}=0.05, \mathrm{CFI}=0.91, \mathrm{IFI}=0.91$ and $\mathrm{TLI}=0.91$-proved that the estimation model was well-fitted for the data. So, hypothesis 1 was validated.

In the structural model 2, the mediator, green business strategies, was included in order to estimate the mediation effect between the green motives and the sustainable development. The adequate values of the ratios $-\chi 2(1999)=3499, \chi 2 / \mathrm{df}=1.75, \mathrm{RMSEA}$ $=0.04, \mathrm{CFI}=0.91, \mathrm{IFI}=0.91$ and TLI $=0.91-$ indicated that the estimation model-2 was well-fitted for the data. The significance of the mediating role of green business strategies was assessed using bootstrapping by selecting a sample of size 2000, according to the criteria elaborated by Hair et al. [103] and Qazi et al. [104]. After introducing GDS as a mediator, its coefficient becomes significant. The bootstrapping results are shown in Table 3.

Table 3. Direct and indirect effects and 95\% confidence intervals (model 2).

\begin{tabular}{cccc}
\hline Parameter & $\boldsymbol{\beta}$ & LL & UP \\
\hline Standardized direct effects & & & \\
GM $\rightarrow$ GBS & $0.32^{*}$ & 0.16 & 0.48 \\
GM $\rightarrow$ SD & $0.08^{*}$ & -0.07 & 0.23 \\
GBS $\rightarrow$ SD & $0.49^{*}$ & 0.34 & 0.62 \\
\hline Standardized indirect effects & & & \\
GM $\rightarrow$ GBS $\rightarrow$ SD & $0.15^{*}$ & 0.07 & 0.27 \\
\hline
\end{tabular}

Notes: * Empirical 95\% confidence interval does not overlap with zero. $n=451$ (bootstrapping by specifying a sample of size 2000). $\mathrm{LL}=$ lower limit. UP = upper limit.

The findings (Table 3) revealed a major positive correlation between GM and GBS $(\beta=0.32$, lower limit $=0.16$ and upper limit $=0.48)$. Thus, hypothesis 2 was supported Likewise, the results proved that there was a significant positive correlation between green business strategies and sustainable development $(\beta=0.49$, lower limit $=0.34$ and upper limit $=0.62$ ). Thus, hypothesis 3 was supported. Importantly, there was a significant 
positive indirect correlation between the GM and the sustainable development through the GBS $(\beta=0.15$, lower limit $=0.17$ and upper limit $=0.27)$. Moreover, after the inclusion of the mediator (green business strategies) in the relationship between the green motives and the sustainable development, the direct correlation between green motives and sustainable development became insignificant. Thus, hypothesis 4 was also supported, suggesting that green business strategies fully mediated the positive correlation between green motives and sustainable development.

The results of the items of the variables (factor loading, AVE and alpha values) included in the questionnaire (for the green motives, green business strategies and sustainable development) and into the analysis are presented in Table 4. Confirmatory factor analysis (CFA) was utilized to test the model validity and model fitness. The reliability, discriminant validity and convergent validity were satisfactory. The discriminant validity and constructs validity were confirmed through CFA, factor loading was greater than 0.70 . We also applied Fornell and Larcker's approach [100] to measure the average variance extracted (AVE) and results show value of AVE was above than 0.50, whereas Cronbach's alpha value was greater than 0.70 .

Table 4. Results of F.L, alpha, CR and AVE.

\begin{tabular}{ccccc}
\hline Variables & FL & AVE & C.R & Alpha \\
\hline Green Motives (10 items) & $(0.82$ to 0.87$)$ & 0.75 & 0.8 & 0.85 \\
Green Business Strategy (21 items) & $(0.82$ to 0.87$)$ & 0.76 & 0.8 & 0.86 \\
Sustainable Development (33 items) & $(0.82$ to 0.87$)$ & 0.77 & 0.8 & 0.87 \\
\hline
\end{tabular}

The results for the major dimensions of the variables (factor loading AVE and Alpha values) included in the questionnaire ( 3 dimensions for the green motives, 6 dimensions for the green business strategies and 4 dimensions for the sustainable development) are presented in Figure 2.

Additionally, the results of the simple linear regression were also calculated to test the $\mathrm{H} 1, \mathrm{H} 2$ and $\mathrm{H} 3$ (see Table 5). Results proved that H1 was accepted. GM predict SD in the hospitality sector $(\mathrm{Beta}=0.9, \mathrm{t}=11.75, \mathrm{Sig}=0.000)$. $\mathrm{H} 2$ was also validated by the results $($ Beta $=0.33, \mathrm{t}=34.71, \mathrm{Sig}=0.000)$; it shows that in the hotel industry it was necessary to build GBS through GM. Actually, GM provide a platform to establish and implement GBS. The H3 has stated that GBS predict SD and this hypothesis was also validated by the achieved results (Beta $=0.48, t=42.26$, Sig $=0.000$ ). SD significantly depended on the strategies related to the green concept in the context of the hospitality sector, as customer were highly sensitive towards environment.

Table 5. Regression result of $\mathrm{H} 1, \mathrm{H} 2$ and $\mathrm{H} 3$.

\begin{tabular}{cccccccc}
\hline Model & Details & $\mathbf{R}^{\mathbf{2}}$ & F-Value & $\boldsymbol{B}$ & $\boldsymbol{t}$-Value & $\boldsymbol{p}$-Value & Remarks \\
\hline Model-1 & GM $\rightarrow$ SD & 0.11 & 64.88 & 0.08 & 11.75 & 0.000 & Accepted \\
Model-2 & GM $\rightarrow$ GBS & 0.06 & 49.26 & 0.32 & 34.71 & 0.000 & Accepted \\
Model-3 & GBS $\rightarrow$ SD & 0.14 & 140.64 & 0.49 & 42.53 & 0.000 & Accepted \\
\hline
\end{tabular}




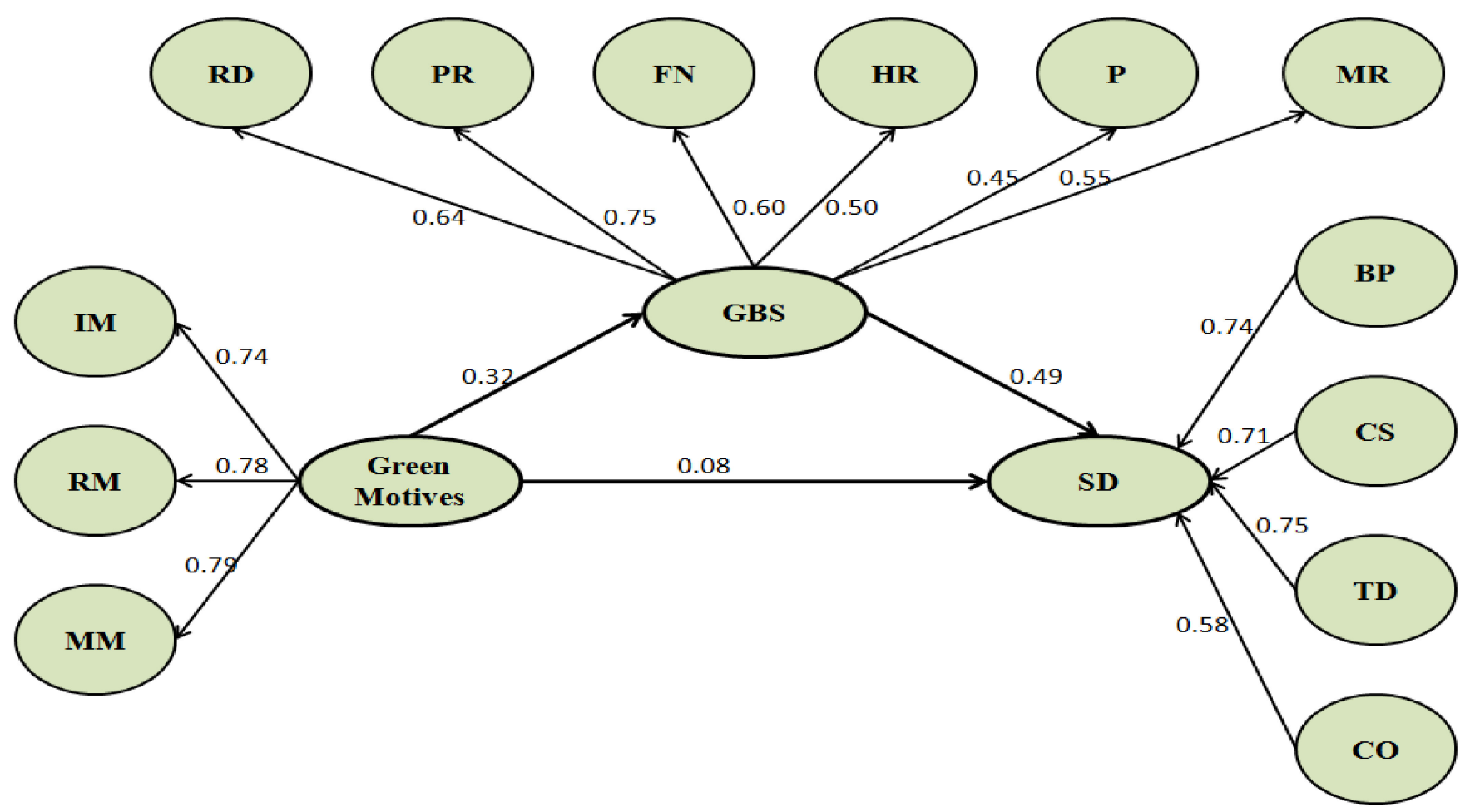

Figure 2. Sustainable development model.

\section{Discussion of the Results}

This study tried to ensure a deeper analysis for the management and other organizational researchers about how GM in term of moral, instrumental and relational motives support the achievement and enhancement of the sustainable development. Therefore, this research connects the GM with GBS and SD. Moreover, the mediating impact of GBS on the correlation between GM and SD was also analyzed. This study aimed to investigate how GM affect SD, and the role of GBS in designing this correlation. Two major reasons of this research were: (a) the need to address and solve the opposite results in the empirical studies and in theoretical approach of the correlation between GM and SD and (b) the need to settle how GBS behaves as a mediator between GM and SD.

In this research we stated four hypotheses to analyze the relation between GM, GBS and SD. All these hypotheses were validated by the achieved results. Regarding H1, we assumed a positive correlation between GM and SD. H2 affirmed a positive link between the GM and GBS. H3 stated there is a direct relation between GBS and SD. The strong relation between GBS and SD proved that the GM cannot represent the only factor impacting on the enhancement of SD; this gives the chance to test the mediation effect of GBS between GM and SD. Hence H4 was tested to check how GBS acts as a mediator in the relation between GM and SD.

Results proved all the hypotheses were accepted. GM predict SD; thus, H1 is accepted. These findings were also validated by previous studies $[45,46,48,54]$. Therefore, we can state that green motives such as moral, instrumental or relational are beneficial for sustainability [45]. The achievement of sustainable development is possible through green motives. Green motives are the key elements that lead to satisfying the stakeholders' environmental demands. The companies can improve their sustainability in a cost-effective way [48] proving that the main motive for hotels to adopt ecolabels is represented by the fact that this is good for the environment, but also for the image of the company. Therefore, the green practices should receive major attention in order to keep the stakeholders motivated for achieving sustainable development. The leading international hotels are strengthening their commitment to sustainability and are integrating it into their strategic plan [54]. 
The findings proved that $\mathrm{H} 2$ is validated; thus, GM positively impact on GBS. The results are according to the empirical findings of other previous studies $[56,57,61,62,105]$. According to these findings it is stated that GM is a major factor supporting the enhancement of GBS. Green business strategies derived from green motives are concerned of adopting manufacturing and service activities, which are safe for the environment and which are sustainable [56]. More companies are actively adopting the green strategies through the green moral motive of business in the perspective of the environmental protection [57]. Green motives support the design of the environmentally friendly policies for implementing some suitable actions [61]. Abdou et al. [64] have also demonstrated that hotels' commitment to the environmental sustainability (a moral green motive) was one of the main GM for adopting green practices in high-rated hotels in Egypt.

Many environmental green practices are applied in the hotel sector. This way, this sector may become ecofriendly and more sustainable in the future. According to some studies, a large share of leisure travelers considers themselves as being 'green' consumers, so the hotels behave accordingly by implementing green practices [106].

Regarding H3, the findings validated that GBS is a positive predictor of SD. The results validated that the SD goals can be achieved by developing GBS. These results are according to the findings of previous studies [39,64,70,71]. Green and sustainable tourism strategies can create a holistic country brand enhancing a further sustainable development in the country [107]. Going green decreases the costs by minimizing the waste and using the resources more effectively in the production process and maintain business sustainability [70]. Furthermore, the green business strategies encourage the mechanism to adopt the latest and modern ideas and improved products, which are ecofriendly for achieving the sustainability goals [71].

Our findings have also confirmed the hypothesis $\mathrm{H} 4$ of this research; thus, the GM predict SD via GBS. GM compel companies to develop their GBS, which, in turn, achieve and improve the SD of their activities. Green motives have supported the green business strategies in more useful way to uplift the business potentials for achieving the ultimate goal of sustainable development [79].

The unexpected results of this study are represented by the low impact of the green motives on SD. Although our findings show that the direct impact of GM on SD was significant, the beta value shows this was much lower comparative to the direct impact of GBS on SD or with the direct impact of GM on GBS. Therefore, we may conclude that GM are not sufficient by themselves to enhance SD. They are important to support GBS and GBS, in turn, supports the SD achievements for the organizations.

\section{Conclusions}

\subsection{Theoretical Contribution}

This research extends the current knowledge on the environmental management with some important research dimensions. The major strength of the current study is that it deals with a complex and enlarged view of GBS, and it does not focus on only one measure of GBS. Measuring more comprehensively the GBS for enhancing SD was scarcely presented in the previous studies and no existing research has tried to build a comprehensive model to evaluate the SD goals through GBS in the organizations.

A second contribution of this research is designing a SD model for the hotels, especially for those operating in the developing economies. The designed SD model displays how the integrated variables-GM and GBS - contribute to the achievement of SD. Thirdly, this study extends the existing knowledge and theory by elaborating a broad scale of SD along with its maximum dimensions in terms of GM and GBS. This is notable contribution of this study to existing body of knowledge, because it builds an extended and comprehensive business sustainable model for hotel industry by incorporating multiple dimensions of GM and GBS. Achieving sustainable development is crucial for the tourism and hotel industry, especially in the developing economies that lack financing sources, because the tourism sector represents a significant financing source for the entire economy. 
Fourth, the strength of the current study is represented by the analysis of the GM in enhancing GBS to the companies. GBS are an important view of the companies concerning ecological issues and effectively reconfigure and reallocate major resources of the organizations to address the environmental problems [108,109]. Adoption of the green practices by the hotels could be considered as follows: minimum use of all the energies, using eco-friendly electrical and mechanical appliances for hot and cold temperatures, serving organic food, minimum use of water, use ecofriendly packaged products, ditching disposables instead of trashing them and low carbon emission [110-112]. Gustin and Weaver [113] stated that customers with GM might be willing to pay more for those hotels, which implement green practices. Hence, the green motive is a significant antecedent of green practices. GM set the way for the implementation of the green practices, as these practices involve all levels of management, stakeholders, materials and processes. Therefore, GM can advocate the green practices in the hotel industry, as stakeholders with their interests follow the green practices for a better image and reputation.

The existing literature did not reach any clear and conclusive evidence on the role of GBS in correlation with their determinant factors and effects. Thus, in order to fill this gap of the current knowledge, this study focuses on GM as a potential explanatory factor of GBS for achieving SD. Another major finding of the analysis is represented by the mediating role of GBS between GM and SD. GBS enhance the positive influence of $\mathrm{GM}$ on the SD. Therefore, we can conclude that all these variables are interconnected and both GM and GBS positively impact on SD. All three dimensions of GM [50] have been analyzed and our results have showed their positive influence on GBS $[46,48]$ and on SD $[56,61]$. Six types of GBS have been included into the analysis, as they have been developed by other authors, Biçakcıŏlu [94] and Yasir [95]. Our results have demonstrated both a direct positive influence on SD [70,71,107], but also a mediating effect of GBS for the GM-SD link. GBS enhance the positive influence of GM on SD. SD was measured by its four dimensions as they have been developed by Singla et al. [97] and concern both environmental sustainability goals, but also efficiency improvements goals based on reducing waste, which is beneficial for the entire society.

\subsection{Practical Implications}

The implications of this study are comprehensive both for the policy makers and managers. Firstly, the obtained results prove that companies can enhance the SD and successfully address to the stakeholders' requirements with the support of GBS by aiming many organizational areas, namely marketing, production, purchasing, R\&D, HR and finance [114]. By doing so, SD can only be achieved when companies consider a holistic view towards the green arrangement. Developing of the individual strategies are not enough to address the stakeholders' requirements and to achieve the goals of SD [115].

Secondly, this research proves that GM have been emphasized as a unique and strong predictor of GBS. Therefore, in order to address to the green issues in the strategies applied by the organizations and to enhance SD, managers must aim the GM that will bring them important information about stakeholders' demands [116]. Thus, the organization management should develop a permanent dialogue among all the stakeholders, to acknowledge their expectations and needs and should address their requirements. This way, the companies can stay competitive and support a sustainable growth of their business.

Since the end of the 1990s, more and more hotels have implemented sustainable practices. Bader [117] has demonstrated that the entire hospitality industry has become the greatest example of sustainable practices that are essential for a business success in the longrun. According to Dube and Nhamo [118], tourism has a central role in economies of many developing countries; therefore, its major role in achieving SDGs is undeniable, especially in the environment area, because environment sustainability represents a significant part of SDGs, but also in the economic area, by improving the overall efficiency of the businesses and of the entire economy, reducing the resources waste and implementing sustainable technological changes that supports the business performance and ensure a sustainable 
economic growth, which is beneficial for the entire society. Through working collectively and sharing best practices of the benefits to environmental commitment, great things can be achieved. The hotel industry must act ecofriendly not only to protect the environment, but also to ensure the future viability and growth of this industry, because this industry is particularly relying on landscapes and see-sights that need to be preserved [58].

Therefore, the policy makers should build a more solid and permanent dialogue among all stakeholders as tourism is a cross-cutting sector, design more integrated tourism policies, supervise the tourism's contribution to the SDGs and support tourism sector, reduce taxes or grant incentives to the tourism organizations in order to support the green motivations of the tourism companies and the implementation of the green business strategies in the tourism sector with the final aim of achieving the sustainable development goals.

\subsection{Limitations and Future Research}

In time, the companies have realized they need to adapt to the new climatic changes, and that made them adopt an environmentally friendly behavior and promotion of social responsible strategies [119]. Sustainability, business model innovation and investment in no-waste and green initiatives were proved to promote a sustainable economic growth and wealth [120] and represent the most efficient way to lift up a country [121].

Even though this research achieves some important results, few limitations must be underlined. Firstly, the study has relied on a quantitative research design. Qualitative research approach might be suitable for a future research. For solving this issue, some mixed research methods could be applied further. We selected the green motives and GBS as major predictors for SD. Further research on this topic can indulge through including other variables that can mediate the relation between green motives and SD. Further, we can also conduct a survey for analyzing the role of GBS in achieving the social dimensions of SDGs (decent work conditions and wages, reducing social inequalities) because in this current research we focused mainly on environmental and economic dimensions of SDGs, by developing and implementing SD business models in the tourism sector, given its high significance for the entire economy all over the world. Lastly, the findings of this research were retrieved from the research survey conducted for the tourism and hotel industries. Another direction for a further research could be represented by a comparison between various international chains and single hotel businesses to find out if there are significant differences as they are for hotels with different rates [64]. The findings of the current research may be sector specific because it has focused on the hotel industry. So, the results might not be generalized to other sectors of large organizations. This model could be applied for SMEs and other sectors in the future, SME representing a large share of the developing economies [122]. The major limitation of this study is that we used subjective measures to analyze data. Next research should include the objective measures too, for attaining deeper insights and because the objective measures are based on how respondents perform specific tasks, irrespective of their experience. Additionally, it is worth emphasizing that this model can be applied in the hotel industry frame in the developed countries. The greening of the economy is a complex process and different from country to country because of the specific features of each economy: level of development, natural resource endowments, strength of institutions and laws, public awareness on the green economy (stakeholders like consumers, businessmen and educational system with a specific role in this process). Therefore, this topic deserves further analysis because it is compatible with the SDGs [123].

Author Contributions: Z.Y., M.R., C.I.S., L.S. Conceptualization, and methodology Z.Y.; Software and validation Z.Y.; Formal analysis L.S.; Investigation M.R., L.M.P.; Resources Z.Y.; Data curation Z.Y.; Writing—original draft preparation M.R., Z.Y.; Writing—review and editing M.R., C.I.S., L.M.P.; Visualization M.R. and Z.Y.; Supervision Z.Y.; Project administration Z.Y. All authors have read and agreed to the published version of the manuscript.

Funding: No funding was received for this research. 
Institutional Review Board Statement: Consent was obtained from the participants, i.e., owner/managers of selected hotels of Pakistan. The research follows the international principles of ethics in research. The Ethics Committee of Government College of Management Sciences approved letter No. GCMS/Man/1937 dated: 3 January 2020.

Data Availability Statement: Data is not available due to confidentiality issue of respondents.

Conflicts of Interest: The authors declare no conflict of interest.

\section{Appendix A}

Table A1. Details of the applied questionnaire and the relation between its questions and the variables used in the analysis.

1. Sustainable Development (Dependent Variable)_Adapted from the Work of Singla et al. (2019) [91]

\section{Competitiveness}
(a) We have established strong technological resource back-up;
(b) We can handle major competitors in the market;
(c) We are able to manufacture the cost-effective products to fulfil the customer's requirements;
(d) Our current market share is sufficient to cope with competition;
(e) Our competitive position will be raised in the next financial year through technological exploits;

(f) Our investment in image, brand and communication has yielded the desirable business outcomes;

(g) We outsourced the production processes to reduce price of products/services;

(h) We have maintained the quality and performance of products/services in diverse situation.

\section{Business Performance Enhancement}
(a) Our hotel conduct productivity analysis on regular basis;
(b) Technological exploits have been facilitated in our hotel to enhance productivity;
(c) We are successful in continuously modifying designing of our products/services;
(d) We systematically measure and manage actual productivity goals;
(e) We successfully continue to enter in new markets;
(f) We accomplish cost reduction/production improvement through new technology;
(g) We have improved logistics and delivery methods;
(h) We make and improved polices to deliver to products/services;
(i) Our hotel established and execute an effective business sustainability plan.

\section{Technological Development}
(a) We are successful in using latest technology;
(b) We used sustainable techniques in effective manner;
(c) We develop technologically competitive products/services with prolonged life cycle;
(d) We have effectively used the upgraded technologies and improved control system;
(e) Our technology is upgraded and stimulates sustainable growth;
(f) We are successful in effecting technological improvement in the existing products/services;
(g) We are successfully evolved environmental-friendly technologies;
(h) We minimize environmental impacts while maintaining social and economic benefits. 
Table A1. Cont.

\section{Customer Satisfaction}

(a) We effectively deal with customer's suggestions;

(b) We effectively act upon the feedback obtained from the customers;

(c) We particularly pay attention to key concerns of customers;

(d) We successfully achieve customer satisfaction;

(e) We are able to effectively meet and streamline customers' requirements;

(f) We provide value-added services to customers;

(g) We effectively communicate about new products/services with customers;

(h) Our customer ordering/tracking system is user friendly and flexible.

2. Green Business Strategies (Mediating Variable)_Adapted from the Work of Bıçakcığlu (2018) [89] and Yasir (2020) [90]

\section{Green Marketing Strategies}

We prefer green (packaging/labelling) of our products/services;

We develop ecological products/services;

We collaborate with the channel members of distribution;

We use environmentally friendly logistics;

We making promotional efforts oriented to save the environment;

We offer special discounts to encourage eco-friendly purchases.

\section{Green R\&D Strategies}

We cooperate activities with external organizations for the implementation of green operations;

We offer those services/products that result in minimal adverse environmental impacts;

We have research team specialized in developing eco-friendly products.

\section{Green Production Strategies}

We have environmental management systems;

We minimize those activities which damage environment;

We implement environmentally friendly production approaches.

\section{Green Human Resources Strategies}

We conduct personnel training related to environmental issues on regular basis;

We focus on authorization related to environmental issues.

\section{Green Purchasing Strategies}

We co-operate with suppliers in order to adhere to environmental objectives;

We prefer the purchase of environmentally friendly raw materials;

We deal with ecologically sensitive suppliers;

We ask suppliers to comply with environmental issues.

\section{Green Finance Strategies}

We distribute budget for environmental issues;

We consider green savings;

We consider environmental costs. 
Table A1. Cont.

\section{Green Motives (Independent Variable)_Adapted from the Work of Chang (2019) [49] Instrumental Motives}

(a) The hotel engages in green activities to avoid poor publicity;

(b) The hotel engages in green activities to appease shareholders;

(c) The hotel engages in green activities for financial profit.

\section{Relational Motives}
(a) The hotel engages in green activities to increase its customer base;
(b) The hotel engages in green activities to differentiate it from its competitors;
(c) The hotel engages in green activities to meet environmental regulations.

\section{Moral Motives}

(a) The hotel engages in green activities because it feels a sense of responsibility for the environment;

(d) The hotel engages in green activities because of a genuine concern for the environment;

(e) The hotel engages in green activities because the high-level managers consider environmental responsiveness a vital part of corporate strategy;

(f) The hotel engages in green activities because it is the right thing to do.

\section{References}

1. Ponce-Ordonez, E.; Khare, A. GRI 300 as a measurement tool for the United Nations sustainable development goals: Assessing the impact of car makers on sustainability. J. Environ. Plan. Manag. 2021, 64, 47-75. [CrossRef]

2. UNWTO; UNDP. Tourism and the Sustainable Development Goals_Journey to 2030; UNWTO World Tourism Organization: Madrid, Spain, 2017.

3. Dube, K. Tourism and Sustainable Development Goals in the African Context. Int. J. Econ. Financ. Stud. 2020, 12, 88-102. [CrossRef]

4. Mbuligwe, S.E. Small Scale Industries and Informal Sector Activity Premises: Environmental and Occupational Health Issues. Encycl. Environ. Health 2011, 95-105.

5. Duarte, B.; Neto, J.M.; Marques, J.C.; Adams, J.B.; Caçador, I. Marine angiosperm indices used to assess ecological status within the Water Framework Directive and South African National Water Act: Learning from differences and common issues. Ecol. Indic. 2017, 83, 192-200. [CrossRef]

6. Koso-Thomas, M.; McClure, E.M. The Global Network for Women's and Children's Health Research: A model of capacity-building research. Semin. Fetal Neonatal Med. 2015, 20, 293-299. [CrossRef] [PubMed]

7. Guziana, B. Is the Swedish environmental technology sector 'green'? J. Clean. Prod. 2011, 19, 827-835. [CrossRef]

8. Fontainha, T.C.; Leiras, A.; de Mello Bandeira, R.A.; Scavarda, L.F. Public-private-people relationship stakeholder model for disaster and humanitarian operations. Int. J. Disaster Risk Reduct. 2017, 2, 371-386. [CrossRef]

9. Thongplew, N.; Spaargaren, G.; van Koppen, C.K. Companies in search of the green consumer: Sustainable consumption and production strategies of companies and intermediary organizations in Thailand. NJAS-Wagening. J. Life Sci. 2017, 83, 12-21. [CrossRef]

10. Hardin-Ramanan, S.; Chang, V.; Issa, T. A Green Information Technology governance model for large Mauritian companies. J. Clean. Prod. 2018, 198, 488-497. [CrossRef]

11. Rex, E.; Baumann, H. Beyond ecolabels: What green marketing can learn from conventional marketing. J. Clean. Prod. 2007, 15, 567-576. [CrossRef]

12. Ma, Y.Y.; Sia, C.L.; Li, Y.; Zheng, S. Sources of resources, alliance green management, and alliance performance in an emerging economy. J. Clean. Prod. 2016, 139, 319-327. [CrossRef]

13. Leonidou, L.C.; Fotiadis, T.A.; Christodoulides, P.; Spyropoulou, S.; Katsikeas, C.S. Environmentally friendly export business strategy: Its determinants and effects on competitive advantage and performance. Int. Bus. Rev. 2015, 24, 798-811. [CrossRef]

14. Baloglu, S.; Raab, C.; Malek, C. Organizational Motivations for Green Practices in Casual Restaurants. Int. J. Hosp. Tour. Adm. 2020, 1-20. [CrossRef]

15. Raab, C.; Baloglu, S.; Chen, Y.S. Restaurant Managers' Adoption of Sustainable Practices: An Application of Institutional Theory and Theory of Planned Behavior. J. Foodserv. Bus. Res. 2018, 21, 154-171. [CrossRef]

16. Siva, V.; Gremyr, I.; Bergquist, B.; Garvare, R.; Zobel, T.; Isaksson, R. The support of Quality Management to sustainable development: A literature review. J. Clean. Prod. 2016, 138, 148-157. [CrossRef] 
17. Landy, M.K.; Roberts, M.J.; Thomas, S.R. The Environmental Protection Agency-Asking the Wrong Questions; Oxford University Press: London, UK, 1990.

18. WTTC. Travel \& Tourism Economic Impact 2016 World. 2016. Available online: http:/ / www.wttc.org/- / media / files / reports / economic\%20impact\%20research/regions\%-202016/world2016.pdf (accessed on 29 November 2020).

19. Ashley, C.; De Brine, P.; Lehr, A.; Wilde, H.; John, F. The Role of the Tourism Sector in Expanding Economic Opportunity; John F. Kennedy School of Government, Harvard University: Cambridge, MA, USA, 2007.

20. Zhang, L.; Gao, J. Exploring the effects of international tourism on China's economic growth, energy consumption and environmental pollution: Evidence from a regional panel analysis. Renew. Sustain. Energy Rev. 2016, 53, 225-234. [CrossRef]

21. Iordache, M.; Cebuc, I. Analysis of the Impact of climate change on tourism in some European countries. Analele Stiintifice ale Universitatii" Alexandru Ioan Cuza" din Iasi-Stiinte Economic 2009, LVI, 270-286.

22. Lenzen, M.; Sun, Y.Y.; Faturay, F.; Ting, Y.P.; Geschke, A.; Malik, A. The carbon footprint of global tourism. Nat. Clim. Chang. 2018, 8, 522-528. [CrossRef]

23. Rentziou, A.; Gkritza, K.; Souleyrette, R.R. VMT, energy consumption and GHS emissions forecasting for passenger transportation. Transp. Res. Part A Policy Pract. 2012, 46, 487-500. [CrossRef]

24. Moon, C. Mass Tourism vs. Sustainable Tourism in the Balearic Islands: Measuring Social and Environmental Impact in Mallorca. Tour. Hosp. 2018, 3, 1-13.

25. Dube, K.; Nhamo, G. Climate change and the aviation sector: A focus on the Victoria Falls tourism route. Environ. Dev. 2019, 29, 5-15. [CrossRef]

26. Gössling, S.; Peeters, P. Assessing tourism's global environmental impact 1900-2050. J. Sustain. Tour. 2015, 23, 639-659. [CrossRef]

27. Scheyvens, R. Linking tourism to the sustainable development goals: A geographical perspective. Tour. Geogr. 2018, 20, 341-342. [CrossRef]

28. Hall, C.M. Constructing sustainable tourism development: The 2030 agenda and the managerial ecology of sustainable tourism. J. Sustain. Tour. 2019, 27, 1044-1060. [CrossRef]

29. Xu, Y.; Jeong, E. The effect of message framings and green practices on customers' attitudes and behavior intentions toward green restaurants. Int. J. Contemp. Hosp. Manag. 2019, 31, 2270-2296. [CrossRef]

30. Dolnicar, S.; Crouch, G.I.; Long, P. Environment-friendly Tourists: What Do We Really Know about Them? J. Sustain. Tour. 2008, 16, 197-210. [CrossRef]

31. Han, H. Travelers' pro-environmental behavior in a green lodging context: Converging value-belief-norm theory and the theory of planned behavior. Tour. Manag. 2015, 47, 164-177. [CrossRef]

32. Freeman, E. Strategic Management: A Stakeholder Approach; Cambridge University Press: Cambridge, UK, 2010.

33. Erdogan, N.; Baris, M.E. Environmental protection programs and conservation practices of hotels in Ankara, Turkey. Tour. Manag. 2007, 28, 604-614. [CrossRef]

34. Page, J.P. Tourism Management: Managing for Change; Elsevier Ltd.: London, UK, 2009.

35. Dissou, Y.; Karnizova, L. Emissions cap or emissions tax? A multi-sector business cycle analysis. J. Environ. Econ. Manag. 2016, 79, 169-188. [CrossRef]

36. Ball, D.J.; Boehmer-Christiansen, S. Societal concerns and risk decisions. J. Hazard. Mater. 2007, 144, 556-563. [CrossRef]

37. Washington, M.; Patterson, K.D. Hostile takeover or joint venture: Connections between institutional theory and sport management research. Sport Manag. Rev. 2011, 14, 1-12. [CrossRef]

38. Namkung, Y.; Jang, S.S. Effects of restaurant green practices on brand equity formation: Do green practices really matter? Int. J. Hosp. Manag. 2013, 33, 85-95. [CrossRef]

39. Fan, Y.; Wu, S.; Lu, Y.; Wang, Y.; Zhao, Y.; Xu, S.; Feng, Y. An approach of measuring environmental protection in Chinese industries: A study using input-output model analysis. J. Clean. Prod. 2016, 137, 1479-1490. [CrossRef]

40. Janoff-Bulman, R.; Sheikh, S.; Baldacci, K.G. Mapping moral motives: Approach, avoidance, and political orientation. J. Exp. Soc. Psychol. 2008, 44, 1091-1099. [CrossRef]

41. Steg, L.; Vlek, C.; Slotegraaf, G. Instrumental-reasoned and symbolic-affective motives for using a motor car. Transp. Res. Part F Traffic Psychol. Behav. 2001, 4, 151-169. [CrossRef]

42. Prouteau, L.; Wolff, F.C. On the relational motive for volunteer work. J. Econ. Psychol. 2008, 29, 314-335. [CrossRef]

43. Simpson, A.; Laham, S.M. Individual differences in relational construal are associated with variability in moral judgment. Personal. Individ. Differ. 2015, 74, 49-54. [CrossRef]

44. Verma, V.K.; Chandra, B. Hotel guest's perception and choice dynamics for green hotel attribute: A mix method approach. Indian J. Sci. Technol. 2016, 9, 1-9. [CrossRef]

45. Zhihong, J.; Jian, H.; Wenzhou, L.; Zhe, C.; Ning, L.; Siyuan, W.; Chang, L. Energy Internet-A New Driving Force for Sustainable Urban Development. Energy Procedia 2018, 152, 1206-1211. [CrossRef]

46. Zou, S.; Guo, L.; Xie, C. Fast recognition of global flow regime in pipeline-riser system by spatial correlation of differential pressures. Int. J. Multiph. Flow 2017, 88, 222-237. [CrossRef]

47. Mora, H.; Pujol-López, F.A.; Mendoza-Tello, J.C.; Morales-Morales, M.R. An education-based approach for enabling the sustainable development gear. Comput. Hum. Behav. 2018, 107, 105775. [CrossRef]

48. Chang, K.C.; Hsu, C.L.; Hsu, Y.T.; Chen, M.C. How green marketing, perceived motives and incentives influence behavioral intentions. J. Retail. Consum. Serv. 2019, 49, 336-345. [CrossRef] 
49. Buunk, E.; van der Werf, E. Adopters versus non-adopters of the green key eco-label in the Dutch accommodation sector. Sustainability 2019, 11, 3563. [CrossRef]

50. Chang, C.H. Do green motives influence green product innovation? The mediating role of green value co-creation. Corp. Soc. Responsib. Environ. Manag. 2019, 26, 330-340. [CrossRef]

51. Aguilera, R.V.; Rupp, D.E.; Williams, C.A.; Ganapathi, J. Putting the S back in corporate social responsibility: A multilevel theory of social change in organizations. Acad. Manag. Rev. 2007, 32, 836-863. [CrossRef]

52. Paulraj, A.; Chen, I.J.; Blome, C. Motives and performance outcomes of sustainable supply chain management practices: A multi-theoretical perspective. J. Bus. Ethics 2017, 145, 239-258. [CrossRef]

53. Testa, F.; Boiral, O.; Iraldo, F. Internalization of environmental practices and institutional complexity: Can stakeholders pressures encourage greenwashing? J. Bus. Ethics 2018, 147, 287-307. [CrossRef]

54. Jones, P.; Hillier, D.; Comfort, D. Sustainability in the global hotel industry. Int. J. Contemp. Hosp. Manag. 2014, 26, 5-17. [CrossRef]

55. Kim, D.H.; Lin, S.C. Human capital and natural resource dependence. Struct. Chang. Econ. Dyn. 2017, 40, 92-102. [CrossRef]

56. Chen, C.C.; Shih, H.S.; Shyur, H.J.; Wu, K.S. A business strategy selection of green supply chain management via an analytic network process. Comput. Math. Appl. 2012, 64, 2544-2557. [CrossRef]

57. Chen, A.; Wu, M.; Chen, K.Q.; Sun, Z.Y.; Shen, C.; Wang, P.Y. Main issues in research and practice of environmental protection for water conservancy and hydropower projects in China. Water Sci. Eng. 2016, 9, 312-323. [CrossRef]

58. Graci, S.; Dodds, R. Why go green? The business case for environmental commitment in the Canadian hotel industry. Anatolia 2008, 19, 251-270. [CrossRef]

59. Molla, A.; Abareshi, A. Organizational green motivations for information technology: Empirical study. J. Comput. Inf. Syst. 2012, $52,92-102$.

60. Wang, X.; Jiang, D.; Lang, X. Future extreme climate changes linked to global warming intensity. Sci. Bull. 2017, 62, 1673-1680. [CrossRef]

61. Masurel, E. Why SMEs invest in environmental measures: Sustainability evidence from small and medium-sized printing firms. Bus. Strategy Environ. 2007, 16, 190-201. [CrossRef]

62. Nulkar, G. SMEs and environmental performance-A framework for green business strategies. Procedia Soc. Behav. Sci. 2014, 133, 130-140. [CrossRef]

63. Dodds, R.; Holmes, M. Is there a benefit from being green? Assessing benefits from marketing sustainability by North American hotels. J. Hotel Bus. Manag. 2016, 5, 145. [CrossRef]

64. Abdou, A.H.; Hassan, T.H.; El Dief, M.M. A Description of Green Hotel Practices and Their Role in Achieving Sustainable Development. Sustainability 2020, 12, 9624. [CrossRef]

65. Milovanovic, S. Balancing Differences and Similarities within The Global Economy: Towards A Collaborative Business Strategy. Procedia Econ. Financ. 2015, 23, 185-190. [CrossRef]

66. Mendling, J.; Baesens, B.; Bernstein, A.; Fellmann, M. Challenges of smart business process management: An introduction to the special issue. Decis. Support Syst. 2017, 100, 1-5. [CrossRef]

67. Ramli, I.; Iskandar, D. Control authority, business strategy, and the characteristics of management accounting information systems. Procedia Soc. Behav. Sci. 2014, 164, 384-390. [CrossRef]

68. Li, Y.; Tan, C.H. Matching business strategy and CIO characteristics: The impact on organizational performance. J. Bus. Res. 2013, 66, 248-259. [CrossRef]

69. Ćetković, J.; Rutešić, S.; Žarković, M.; Knežević, M.; Vatin, N. Primary directions and advancements in competitiveness of montenegrin construction sector. Procedia Eng. 2015, 117, 775-785. [CrossRef]

70. Salem, D.; Bakr, A.; El Sayad, Z. Post-construction stages cost management: Sustainable design approach. Alex. Eng. J. 2018, 57, 3429-3435. [CrossRef]

71. Sinakou, E.; Boeve-de Pauw, J.; Goossens, M.; Van Petegem, P. Academics in the field of Education for Sustainable Development: Their conceptions of sustainable development. J. Clean. Prod. 2018, 184, 321-332. [CrossRef]

72. Liu, Z.Y.; Sealy, M.P.; Li, W.; Zhang, D.; Fang, X.Y.; Guo, Y.B.; Liu, Z.Q. Energy consumption characteristics in finish hard milling. J. Manuf. Process. 2018, 35, 500-507. [CrossRef]

73. Shen, L.; Qian, J.; Chen, S.C. Effective communication strategies of sustainable hospitality: A qualitative exploration. Sustainability 2020, 12, 6920. [CrossRef]

74. Abdel-Maksoud, A.; Kamel, H.; Elbanna, S. Investigating relationships between stakeholders' pressure, eco-control systems and hotel performance. Int. J. Hosp. Manag. 2016, 59, 95-104. [CrossRef]

75. Imran, R.; Dennis, R.; Stefani, S. How 'green' are North American hotels? An exploration of low-cost adoption practices United States. Int. J. Hosp. Manag. 2012, 31, 720-727.

76. Krell, K.; Matook, S.; Rohde, F. The impact of legitimacy-based motives on IS adoption success: An institutional theory perspective. Inf. Manag. 2016, 53, 683-697. [CrossRef]

77. Paul, A.; Lang, J.W.; Baumgartner, R.J. A multilevel approach for assessing business strategies on climate change. J. Clean. Prod. 2017, 160, 50-70. [CrossRef]

78. Kallmuenzer, A.; Peters, M. Innovativeness and control mechanisms in tourism and hospitality family firms: A comparative study. Int. J. Hosp. Manag. 2018, 70, 66-74. [CrossRef] 
79. Best, M.N.; Thapa, B. Motives, facilitators and constraints of environmental management in the Caribbean accommodations sector. J. Clean. Prod. 2013, 52, 165-175. [CrossRef]

80. Bah, E.H.; Fang, L. Impact of the business environment on output and productivity in Africa. J. Dev. Econ. 2015, 114, 159-171. [CrossRef]

81. Yuen, K.F.; Thai, V.V.; Wong, Y.D. The effect of continuous improvement capacity on the relationship between of corporate social performance and business performance in maritime transport in Singapore. Transp. Res. Part E Logist. Transp. Rev. 2016, 95, 62-75. [CrossRef]

82. Stock, T.; Obenaus, M.; Kunz, S.; Kohl, H. Industry 4.0 as enabler for a sustainable development: A qualitative assessment of its ecological and social potential. Process Saf. Environ. Prot. 2018, 118, 254-267. [CrossRef]

83. Gao, Y.L.; Mattila, A.S. Improving consumer satisfaction in green hotels: The roles of perceived warmth, perceived competence, and CSR motive. Int. J. Hosp. Manag. 2014, 42, 20-31. [CrossRef]

84. Van Bommel, K. Managing tensions in sustainable business models: Exploring instrumental and integrative strategies. J. Clean. Prod. 2018, 196, 829-841. [CrossRef]

85. Bolderdijk, J.W.; Steg, L.; Geller, E.S.; Lehman, P.K.; Postmes, T. Comparing the effectiveness of monetary versus moral motives in environmental campaigning. Nat. Clim. Chang. 2013, 3, 413-416. [CrossRef]

86. Anser, M.K.; Yousaf, Z.; Usman, M.; Yousaf, S. Towards Strategic Business Performance of the Hospitality Sector: Nexus of ICT, E-Marketing and Organizational Readiness. Sustainability 2020, 12, 1346. [CrossRef]

87. Butz, D.A.; Cook, N.E. Accessibility interrupted: The Shimshal road, Gilgit-Baltistan, Pakistan. Can. Geogr. Le Géographe Can. 2011, 55, 354-364. [CrossRef]

88. Raza, S.A.; Jawaid, S.T. Terrorism and tourism: A conjunction and ramification in Pakistan. Econ. Model. 2013, 33, 65-70. [CrossRef]

89. Majid, A.; Yasir, M.; Yousaf, Z.; Qudratullah, H. Role of network capability, structural flexibility and management commitment in defining strategic performance in hospitality industry. Int. J. Contemp. Hosp. Manag. 2019, 31, 3077-3096. [CrossRef]

90. Ahmed, M.; Guo, Q.; Qureshi, M.A.; Raza, S.A.; Khan, K.A.; Salam, J. Do green HR practices enhance green motivation and proactive environmental management maturity in hotel industry? Int. J. Hosp. Manag. 2021, 94, 102852. [CrossRef]

91. Khaskheli, A.; Jiang, Y.; Raza, S.A.; Qureshi, M.A.; Khan, K.A.; Salam, J. Do CSR activities increase organizational citizenship behavior among employees? Mediating role of affective commitment and job satisfaction. Corp. Soc. Responsib. Environ. Manag. 2020, 27, 2941-2955. [CrossRef]

92. Podsakoff, P.M.; Mac Kenzie, S.B.; Lee, J.Y.; Podsakoff, N.P. Common method biases in behavioral research: A critical review of the literature and recommended remedies. J. Appl. Psychol. 2003, 88, 879-903. [CrossRef] [PubMed]

93. Hair, J.F.; Black, W.C.; Babin, B.J.; Anderson, R.E. Multivariate Data Analysis, 7th ed.; Prentice-Hall: Upper Saddle River, NJ, USA, 2010.

94. Raza, S.A.; Qazi, W.; Khan, K.A.; Salam, J. Social Isolation and Acceptance of the Learning Management System (LMS) in the time of COVID-19 Pandemic: An Expansion of the UTAUT Model. J. Educ. Comput. Res. 2020. [CrossRef]

95. Bıçakcığlu, N. Green Business Strategies of Exporting Manufacturing Firms: Antecedents, Practices, and Outcomes. J. Glob. Mark. 2018, 31, 246-269. [CrossRef]

96. Yasir, M.; Majid, A.; Yasir, M.; Qudrat-Ullah, H. Promoting environmental performance in manufacturing industry of developing countries through environmental orientation and green business strategies. J. Clean. Prod. 2020, 275, 123003. [CrossRef]

97. Jovane, F.; Yoshikawa, H.; Alting, L.; Boer, C.R.; Westkamper, E.; Williams, D.; Paci, A.M. The incoming global technological and industrial revolution towards competitive sustainable manufacturing. CIRP Ann. 2008, 57, 641-659. [CrossRef]

98. Singla, A.; Ahuja, I.S.; Sethi, A.S. An examination of effectiveness of technology push strategies for achieving sustainable development in manufacturing industries. J. Sci. Technol. Policy Manag. 2019, 10, 73-101. [CrossRef]

99. Bürgi, H.B.; Dunitz, J.D. Structure Correlation; John Wiley \& Sons: Hoboken, NJ, USA, 2008.

100. Fornell, C.; Lacker, D.F. Structural equation models with unobservable variables and measurement error: Algebra and Statistics. J. Mark. Res. 1981, 18, 382-388. [CrossRef]

101. Ringle, C.; da Silva, D.; Bido, D. Structural Equation Modelling with the SmartPLS Brazilian. J. Mark. $2014,13,56-73$.

102. Henseler, J.; Ringle, C.M.; Sinkovics, R.R. The use of partial least squares path modeling in international marketing. In New Challenges to International Marketing (Advances in International Marketing, Vol. 20); Sinkovics, R.R., Ghauri, P.N., Eds.; Emerald Group Publishing Limited: Bingley, UK, 2009; pp. 277-319.

103. Hair, J.F.; Ringle, C.M.; Sarstedt, M. PLS-SEM: Indeed a silver bullet. J. Mark. Theory Pract. 2011, 19, 139-151. [CrossRef]

104. Qazi, W.; Qureshi, J.A.; Raza, S.A.; Khan, K.A.; Qureshi, M.A. Impact of personality traits and university green entrepreneurial support on students' green entrepreneurial intentions: The moderating role of environmental values. J. Appl. Res. High. Educ. 2020, in press. [CrossRef]

105. Guoyou, Q.; Saixing, Z.; Chiming, T.; Haitao, Y.; Hailiang, Z. Stakeholders' influences on corporate green innovation strategy: A case study of manufacturing firms in China. Corp. Soc. Responsib. Environ. Manag. 2013, 20, 1-14. [CrossRef]

106. Miller, M.; Mayer, K.J.; Baloglu, S. Importance of green hotel attributes to business and leisure travellers. J. Hosp. Mark. Manag. 2012, 21, 395-413.

107. Jamrozy, U. Sustainable Tourism Development: Ingenuity In Marketing Strategy. WIT Trans. Ecol. Environ. Sustain. Dev. Sustain. Tour. III 2008, 115, 65-72. 
108. Groening, C.; Sarkis, J.; Zhu, Q. Green marketing consumer-level theory review: A compendium of applied theories and further research directions. J. Clean. Prod. 2018, 172, 1848-1866. [CrossRef]

109. Ottman, J. The New Rules of Green Marketing: Strategies, Tools, and Inspiration for Sustainable Branding; Routledge: London, UK, 2017.

110. Hahnel, U.J.; Gölz, S.; Spada, H. How does green suit me? Consumers mentally match perceived product attributes with their domain-specific motives when making green purchase decisions. J. Consum. Behav. 2014, 13, 317-327. [CrossRef]

111. Ham, S.; Lee, S. US restaurant companies' green marketing via company websites: Impact on financial performance. Tour. Econ. 2011, 17, 1055-1069. [CrossRef]

112. Lo, A.Y.; Jim, C.Y. The willingness of residents to pay and motives for the conservation of urban green spaces in the compact city of Hong Kong. Urban For. Urban Green. 2010, 9, 113-120. [CrossRef]

113. Gustin, M.E.; Weaver, P.A. Are hotels prepared for the environmental consumer? Hosp. Res. J. 1996, 20, 1-14. [CrossRef]

114. Porter, M.E.; van der Linde, C. Toward a New Conception of the Environment-Competitiveness Relationship. J. Econ. Perspect. 1995, 9, 97-118. [CrossRef]

115. Renwick, D.W.S.; Redman, T.; Maguire, S. Green Human Resource Management: Areview and research agenda. Int. J. Manag. Rev. 2013, 15, 1-14. [CrossRef]

116. Feng, M.; Yu, W.; Wang, X.; Wong, C.Y.; Xu, M.; Xiao, Z. Green supply chain management and financial performance: The mediating roles of operational and environmental performance. Bus. Strategy Environ. 2018, 27, 811-824. [CrossRef]

117. Bader, E.E. Sustainable Hotel Business Practices. J. Retail Leis. Prop. 2005, 5, 70-77. [CrossRef]

118. Dube, K.; Nhamo, G. Climate change and potential impacts on tourism: Evidence from the Zimbabwean side of the Victoria Falls. Environ. Dev. Sustain. 2018, 21, 2025-2041. [CrossRef]

119. Voica, M.C.; Panait, M.; Radulescu, I. Green investments-between necessity, fiscal constraints and profit. Procedia Econ. Financ. 2015, 22, 72-79. [CrossRef]

120. Hysa, E.; Kruja, A.; Rehman, N.U.; Laurenti, R. Circular Economy Innovation and Environmental Sustainability Impact on Economic Growth: An Integrated Model for Sustainable Development. Sustainability 2020, 12, 4831. [CrossRef]

121. Mansi, E.; Hysa, E.; Panait, M.; Voica, M.C. Poverty-A Challenge for Economic Development? Evidences from Western Balkan Countries and the European Union. Sustainability 2020, 12, 7754.

122. Yousaf, Z.; Majid, A. Organizational network and strategic business performance. J. Organ. Chang. Manag. 2018, 31, 2-22. [CrossRef]

123. Ene, C.; Voica, M.C.; Panait, M. Green investments and food security: Opportunities and future directions in the context of sustainable development. In Measuring Sustainable Development and Green Investments in Contemporary Economies; Mieila, M., Ed.; IGI Global: Hershey, PA, USA, 2017; pp. 163-200. 